\title{
A comparison of various seaweed-based diets and formulated feed on growth rate of abalone in a land-based aquaculture system
}

\author{
Krishni Naidoo ${ }^{1}$, Gavin Maneveldt*1, Kevin Ruck², John J. Bolton ${ }^{3}$ \\ ${ }^{1}$ Department of Biodiversity and Conservation Biology, University of the Western Cape, Private Bag \\ X17, Bellville 7535, South Africa \\ 2Jacobsbaai Sea Products Farm, Private Bag X2, Rhine Road, Jacobsbaai 8050, South Africa \\ ${ }^{3}$ Department of Botany, University of Cape Town, Rondebosch 7701, South Africa \\ *Corresponding author: gmaneveldt@uwc.ac.za
}

Key words: abalone, diet, growth, seaweed, Ecklonia, Haliotis midae.

\section{Abstract}

The effects of different diets on growth in the cultured South African abalone, Haliotis midae (Linnaeus), was investigated. Growth of juvenile Haliotis midae was monitored on a commercial abalone farm over a period of 9-months in an experiment consisting of 9 treatments with 4 replicates $(n=250$ individuals per replicate). The treatments were: fresh kelp (Ecklonia maxima) blades (seaweed control); Abfeed $\AA$ (formulated feed control); kelp + Abfeed $\AA$; dried kelp pellets; dried kelp blades; dried kelp stipes; fresh kelp with the epiphyte Carpoblepharis flaccida; a mixed diet (Gracilaria gracilis, Ulva lactuca, and kelp) and a rotational diet (abalone were fed 1 of the 9 treatments for the first week and them kelp for the next 3 weeks). Results show that abalone grow well on all fresh seaweed combinations, but do best on a mixed diet. The likely reason for the success of the mixed diet is that the red and green seaweed was farm grown, with an increased protein content. Dried kelp in any form produced poor growth. Abalone fed on the mixed diet grew at $0.066 \mathrm{~mm}^{\text {day }}{ }^{-1}$ shell length and $0.074 \mathrm{~g}^{-1}{ }^{-1}$ body weight; this corresponds to $24.09 \mathrm{~mm}$ shell length and $27.01 \mathrm{~g}$ body weight increase per annum. Abalone fed on dried kelp grew at only $0.029 \mathrm{~mm}^{2}$ day $^{-1}$ shell length and of $0.021 \mathrm{~g}$ day $^{-1}$ body weight. Abalone grown on Abfeed $\AA$ grew at $0.049 \mathrm{~mm}^{-1 a y^{-1}}$ shell length and $0.046 \mathrm{~g} \mathrm{day}^{-1}$ body weight which corresponds to $17.88 \mathrm{~mm}$ and $16.79 \mathrm{~g}$ increase per annum; this is better than the dried seaweed feeds, but poorer than the fresh seaweed combinations. This study shows that seaweed diets, particularly if the diets include seaweeds grown in animal aquaculture effluent, are good substitutes for the formulated feeds generally used today.

\section{Introduction}

The South African abalone, Haliotis midae Linn., is a highly sought after delicacy in the Far East, which is also the destination of $90 \%$ of the product from the local fishery (Britz et al., 1994). Of 6 abalone species in South Africa, only H. midae is presently fished commercially. Although the South African abalone fishery has existed since 1949 , the first attempts at cultivating $H$. midae commercially were only made in 1981 when captured specimens were successfully spawned to produce spat and juvenile abalone (Genade et al., 1988). As of 2001, twelve abalone farms, with an estimated investment of US\$12 million, had been established on the South African coast (Sales \& Britz, 2001). By 2003, this value had increased to 18 farms, with a 
projected production of 527 and 700 tons per annum for 2003 and 2004 respectively (Gerber, 2004).

The proper nutrition and the resulting growth of cultured abalone are critical factors in the successful culture of this animal. While $H$. midae can reach a maximum size of about $200 \mathrm{~mm}$ shell length at an age of over 30 years in the wild, farm production is aimed towards an average size of only $100 \mathrm{~mm}$, which is currently achieved after 5 years (Sales \& Britz, 2001). Abalone growth is extremely slow and quite often varies with size and age. Diet is therefore very important and it has been shown that different diets produce different growth rates (Leighton, 1974; Britz, 1996a; Guzmán \& Viana, 1998; Shpigel et al., 1999; Boarder \& Shpigel, 2001; Bautista-Teruel et al., 2003).

Abalone begin to feed immediately after larval settlement, initially consuming benthic diatoms (Tutschulte \& Connell, 1988). As they grow, they begin feeding on macroalgae and may change from one species of macroalgae to another as they mature (Stepto \& Cook, 1993). Preferences exist, with red algae being favoured by a number of different abalone species (Tutschulte \& Connell, 1988; Shepherd \& Steinberg, 1992; Stepto \& Cook, 1993; Fleming, 1995). Juveniles begin to eat macroalgae at about 10mm shell length and will eat from 10 to $30 \%$ of their body weight in algae each day and have high feeding rates that are due to the high water content and relatively low protein content of macroalgae (Hahn, 1989).

Research conducted thus far has dealt mainly with the natural diet of wild abalone, single-species diets in culture, and more recently, the production of formulated diets (Simpson \& Cook, 1998; Sales \& Janssens, 2004). Wild abalone generally feed on a broad selection of algae, normally with at least two species being found in the gut at any one time (Barkai \& Griffiths, 1986). This implies that abalone typically select more than just a single species and preferentially choose a mixture of algae. In this study we test the effects of various diets on the growth of juvenile abalone in commercial aquaculture systems, including a formulated feed, dry and fresh kelp, and a mixture of kelp, kelp epiphytes, and farm grown seaweed.

Materials and methods

\section{Experimental animals}

Abalone of a specific age class often vary in size because of their differential feeding rates. For this reason, juvenile abalone of the same age and similar size were chosen as test animals. Hatchery-reared animals (from the Jacobsbaai Sea Products farm), spawned in September 2002, approximately 22 months old, $34.7 \pm 5.8 \mathrm{~mm}$ in shell length, and $7.8 \pm 3.8 \mathrm{~g}$ in body weight, were used to test the growth response of juvenile abalone fed on 9 different diets. Flow through seawater $\left(700 \pm 100 \mathrm{Lh}^{-1}\right)$, moderately aerated, was supplied at a temperature of $15.5 \pm 2.5{ }^{\circ} \mathrm{C}$ in the holding tanks. Abalone were grown in culture baskets, with a stocking density of $5 \mathrm{~kg}( \pm 500$ individuals) per basket. Each basket was subdivided, using mesh, to produce 2 replicates (a stocking density of \pm 250 individuals per replicate) and two baskets were used for each treatment, i.e. $\mathrm{n}=4$ replicates. Growth was monitored over a 9-month period.

\section{Diets}


The 9 diets consisted of: fresh kelp (Ecklonia maxima [Osbeck] Papenf.) blades (seaweed control); Abfeed $\AA$ (formulated feed control); kelp + Abfeed®; dried kelp pellets; dried kelp blades; dried kelp stipes, kelp with a red algal epiphyte (Carpoblepharis flaccida [C.Ag.] Kütz.); a mixed diet (Gracilaria gracilis [Stackhouse] Steentoft, Irvine et Farnham, Ulva lactuca L. and kelp); and a rotation diet (where the abalone were fed 1 of the 9 treatments for the first week, and then kelp for the following 3 weeks). Abfeed $囚$ (Sea Plant Products Ltd, South Africa) is an abalone formulated feed containing fishmeal (55\%), starch, Spirulina spp. (10 \%), vitamins and minerals (Fleming et al., 1996). The approximate analysis of Abfeed $\AA$ is $34.6 \%$ protein, $43.3 \%$ carbohydrates, $5.3 \%$ fat, $1.2 \%$ Crude fibre, $5.7 \%$ ash and $\sim 10 \%$ moisture (Sea Plant Products Ltd, pers. com.). All kelp was harvested locally. Kelp was chosen as a seaweed control because it is this seaweed that is most commonly used as fresh abalone feed in South Africa. Abfeed ${ }^{\circledR}$ was used as an formulated control feed because it is the most common artificial food pellet used on commercial abalone farms in South Africa. Ulva lactuca and G. gracilis for the mixed diet were obtained on the farm from a cultured stock grown in abalone and fish (turbot) effluent. These seaweeds grown in abalone and turbot effluent have considerably increased nitrogen content over that of seaweed collected from local seashores (Robertson-Andersson, 2004; Robertson-Andersson et al., 2005). Ulva lactuca grown in these systems has an average protein content of $33.4 \%$ when grown in abalone waste, and $36.6 \%$ when grown in turbot waste as opposed to $3.7-19.9 \%$ in wild $U$. lactuca (Robertson-Andersson, 2004). No protein values were available for G. gracilis but it is assumed that farm grown G. gracilis will also have considerably higher protein content than wild G. gracilis.

Representative animals were selected from each treatment $(\mathrm{n}=30$ at $0-2$ months, $\mathrm{n}$ $=40$ at 3-8 months and $n=50$ at 9 months to compensate for differential growth). Abalone shell length and body weight were measured once a month for 9 months. Daily growth rates in terms of body weight (DGBW) and shell length (DGSL) were calculated as follows:

DGBW $=(\mathrm{W} 1-\mathrm{Wo}) / \mathrm{t}$

DGSL $=($ L1 - Lo $) / t$

Wo - mean initial weight, $\mathrm{W} 1=$ mean final weight, $\mathrm{Lo}=$ mean initial length, $\mathrm{L} 1=$ mean final length, and $\mathrm{t}=$ time in days.

\section{Body Weight/Shell Length Ratio}

The body weight-to-shell length ratio (BW/SL) was calculated for all 9 diet treatments. The BW/SL ratio (Mean final weight / Mean final length) gives an indication of the flesh volume per unit shell length growth for each of the 9 diet treatments. BW/SL rations are important in that they indicate the mass of abalone per unit shell length. Thus at marketable size $(80 \mathrm{~mm}-100 \mathrm{~mm})$, the value of an abalone priced by weight will be dependent on the BW/SL ratio. Certain diets will therefore produce more valuable abalone.

\section{Statistical analysis}

All data are expressed as means \pm se. A two-way analysis of variance (ANOVA: Zar, 1984) was used to compare and analyze the effect of the various treatments on shell length and body weight over time. Differences among treatment means were considered significant at $P<0.05$. 
Results

Diets

Dried kelp in any form (blades, stipes, and pellets) produced poor growth in both weight $(P<0.05)$ and shell length $(P<0.05)$ when compared against the fresh

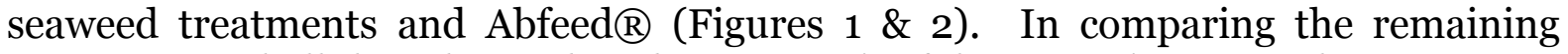
treatments, shell length produced no meaningful comparison, as there was no

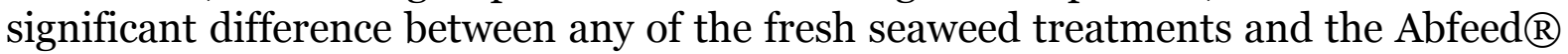
$(P=0.37)$. Body weight, however, produced more meaningful differences.

There were significant differences in body weight between treatments after only 5 months $(P<0.05)$. The mixed diet $\left(0.074 \mathrm{~g}\right.$ day $\left.{ }^{-1}\right)$ produced the best growth followed by the rotation diet and epiphyte treatments (0.059 $\left.\mathrm{g} \mathrm{day}^{-1}\right)$, and then the fresh kelp diet (0.056 $\left.\mathrm{g}_{\text {day }}{ }^{-1}\right)$. A surge in growth can be seen after month 7 (Figure $2)$. This is due to a thinning of the sample size ( $n=150$ per replicate) as growth of the sample had become density dependent by month 7 . Generally those diets that contained more than one seaweed and those that included Abfeed $囚$, produced good growth rates (Tables $1 \& 2$; Figures 1 \& 2).

Table 1. Mean shell length and growth rates of juvenile abalone fed over the 9-month growth period (270 days).

\begin{tabular}{|c|c|c|c|c|c|}
\hline Diet Treatment & & Mean Initial & Mean Final & Growth & $\begin{array}{l}\text { Growth } \\
\text { Rate }\end{array}$ \\
\hline & & $\begin{array}{l}\text { Length (IIIII } \pm \\
\text { se) }\end{array}$ & $\begin{array}{l}\text { Length (IIIII } \pm \\
\text { se) }\end{array}$ & $\begin{array}{l}\text { Rate } \\
\left(\mathrm{mm} \mathrm{dav}^{-1}\right)\end{array}$ & (mm.year-1 \\
\hline Mixed diet & & $2471+020$ & $5260+024$ & 0066 & ) \\
\hline Fresh kelp & + & $34 . / 4 \pm 0.20$ & $5^{2.00} \pm 0.24$ & & \\
\hline Epiphyte & & $33.81 \pm 0.18$ & $49.94 \pm 0.25$ & 0.060 & 21.90 \\
\hline Rotation & & $34.76 \pm 0.20$ & $50.35 \pm 0.23$ & 0.058 & 21.17 \\
\hline Fresh kelp & & $34.45 \pm 0.21$ & $49.24 \pm 0.24$ & 0.055 & 20.07 \\
\hline Fresh kelp & + & & & & \\
\hline Abfeed $\mathbb{R}$ & & $34.75 \pm 0.18$ & $49.09 \pm 0.25$ & 0.053 & 19.34 \\
\hline Abfeed@ & & $34.04 \pm 0.18$ & $47.27 \pm 0.25$ & 0.049 & 17.88 \\
\hline Dried blade & & $34.34 \pm 0.19$ & $43.53 \pm 0.19$ & 0.034 & 12.41 \\
\hline Dried stipe & & $34.31 \pm 0.18$ & $42.82 \pm 0.21$ & 0.032 & 11.31 \\
\hline Dried kelp pellets & & $34.58 \pm 0.20$ & $42.36 \pm 0.18$ & 0.029 & 10.58 \\
\hline
\end{tabular}


Fig. 1. Growth in abalone shell length for all diet treatments over the 9-month period.

Naidoo et al. Figure 1.

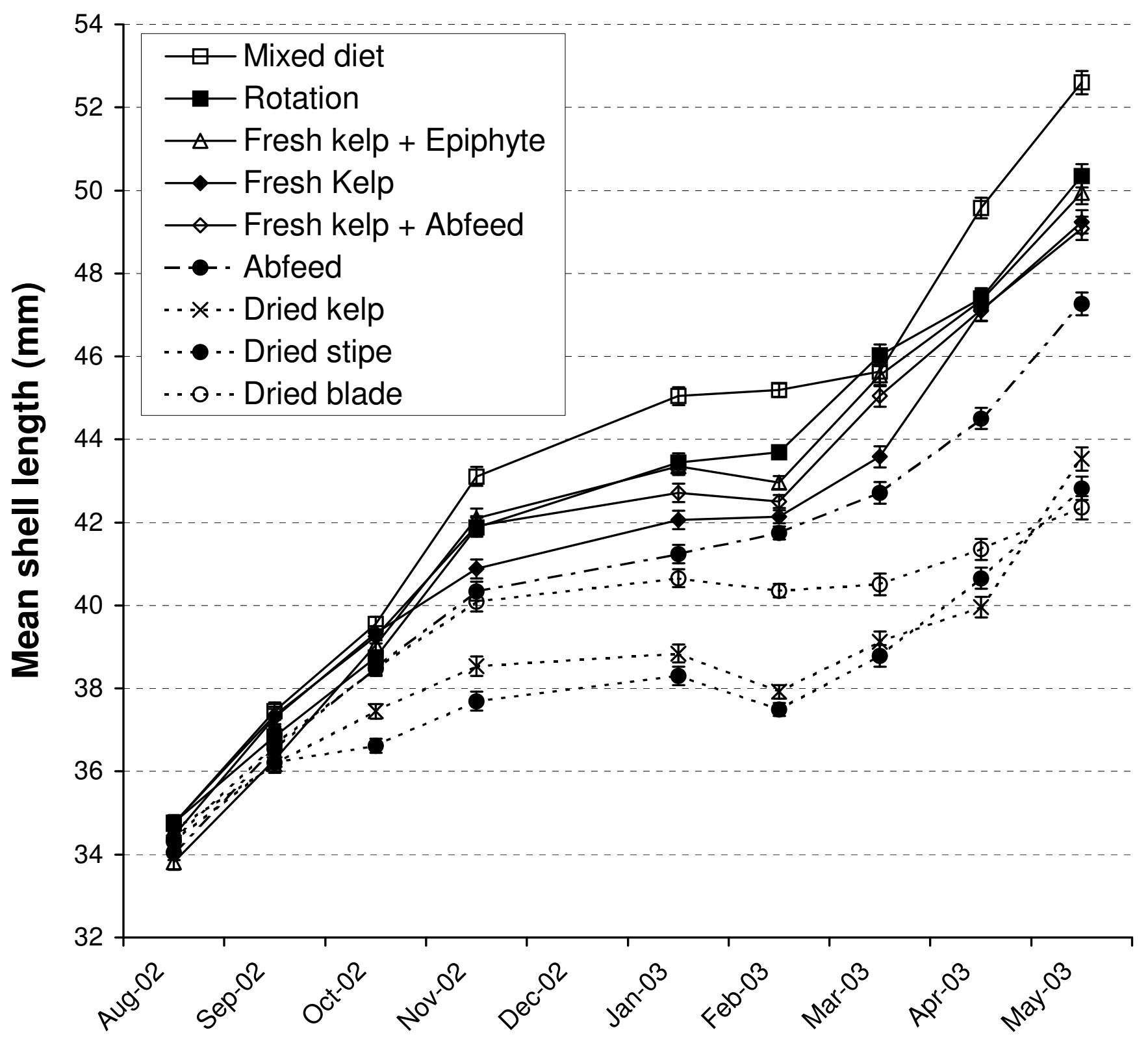

The mixed diet, ranked 1, produced the best growth rates for both shell length (0.066 $\mathrm{mm}$ day $^{-1}$ ) and body weight (0.074g day-1). Abfeed ${ }^{\circledR}\left(0.049 \mathrm{~mm}^{-1 a y^{-1}}\right.$ shell length $\& 0.046$ g day $^{-1}$ body weight), ranked 6 , did not perform as well as the combination feeds, but still performed better than the dried seaweed treatments. Dried kelp (pellets and blades) produced the lowest growth (Tables 1 \& 2; Figures 1 \& 2). 
Table 2. Mean wet weight, growth rates and BW/SL ratios of juvenile abalone fed over the 9-month growth period (270 days) by increasing order of dietary rank.

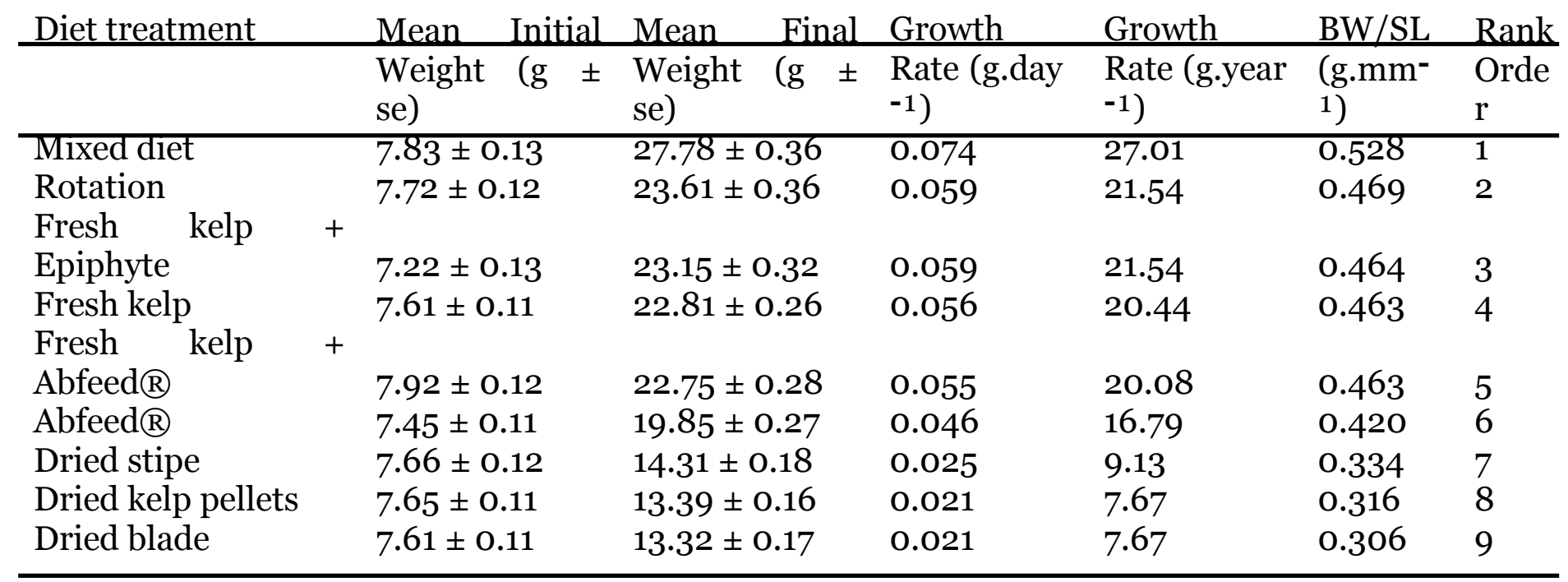




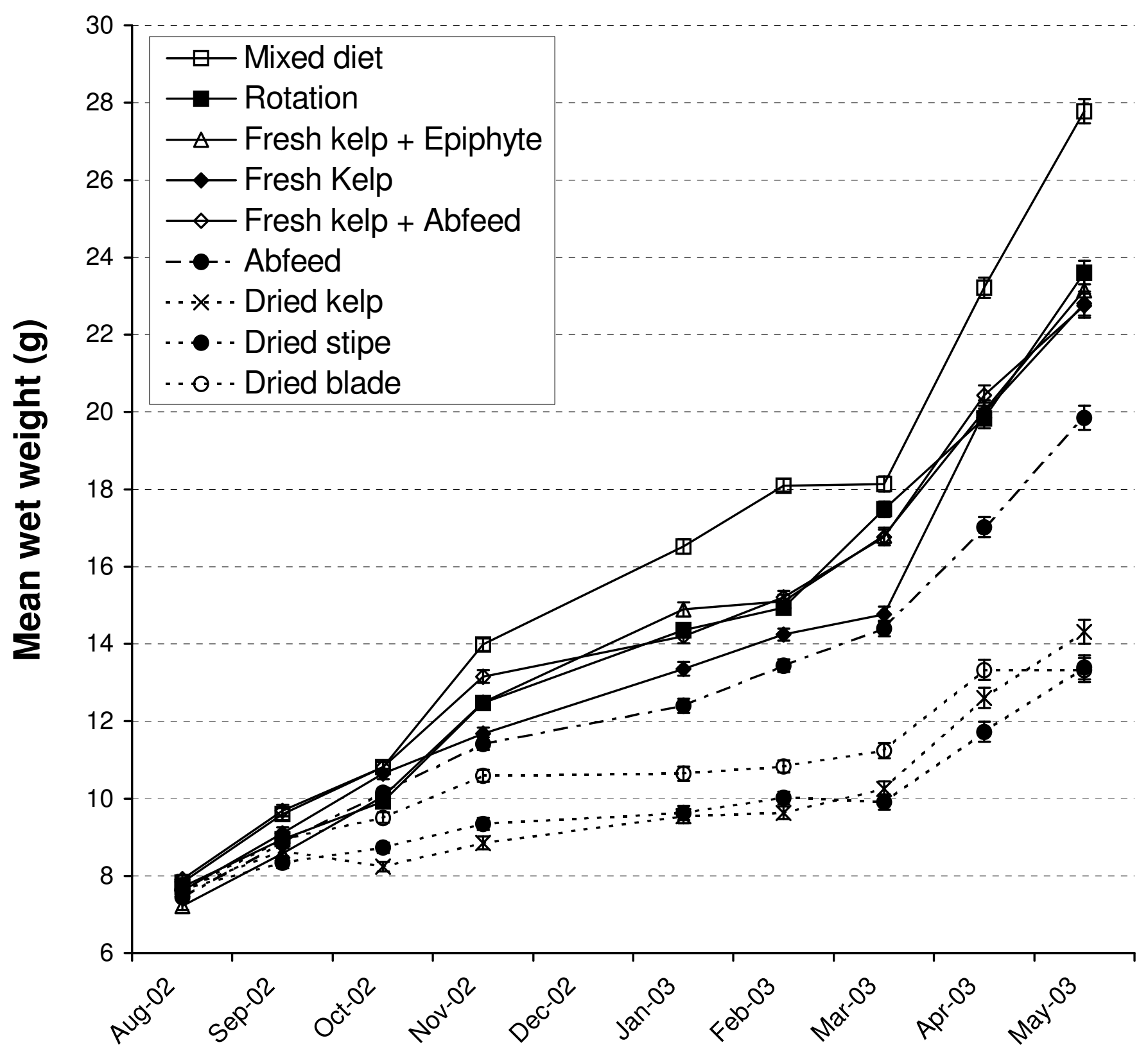

Naidoo et al. Figure 2.

Fig. 2. Growth in abalone body weight for all diet treatments over the 9-month period. 


\section{$B W / S L$ ratios}

The mixed diet produced the highest BW/SL ratio $\left(0.528 \mathrm{~g} \mathrm{~mm}^{-1}\right)$ and the dried blade treatment the lowest $\left(0.306 \mathrm{~g} \mathrm{~mm}^{-1}\right)$ (Table 2). Again the BW/SL ratios were generally higher for the diet treatments that contained a combination of feeds i.e., the mixed diet $\left(0.528 \mathrm{~g} \mathrm{~mm}^{-1}\right.$, ranked 1$)$, the rotation diet $\left(0.469 \mathrm{~g} \mathrm{~mm}^{-1}\right.$, ranked 2), the epiphyte diet (0.464 $\mathrm{g} \mathrm{mm}^{-1}$, ranked 3), and the kelp + Abfeed $囚$ diet $\left(0.463 \mathrm{~g} \mathrm{~mm}^{-1}\right.$, ranked 5). The kelp only diet produced a comparatively good BW/SL ratio (ranked 4 at $0.463 \mathrm{~g} \mathrm{~mm}^{-1}$ ).

\section{Discussion}

Good growth rates are important in ensuring that cultured animals reach a marketable size and condition within a time that is economically viable. Previous studies on Haliotis sp. have shown that "mixed" diets produce better growth rates than single-species diets (Owen et al., 1984; Day \& Fleming, 1992; Fleming, 1995, Simpson \& Cook, 1998). Wild $H$. midae, in particular, are found to have a variety of algae in their guts, with $E$. maxima forming the larger percentage of the gut contents, followed by red or green algae (Newman, 1968; Barkai \& Griffiths, 1986; 1987). This suggests that abalone are naturally selecting a mixture of seaweeds.

Our data are consistent with previously published works in that abalone grown on a combination of different seaweeds perform better than those grown on a single species. Single-species diets, and in particular dried feeds, produce poor growth in abalone. Duncan \& Klekowski (1975), for example stated that essential nutrients might become limiting in experiments where animals are fed single-species diets, which could result in poor growth rates. Various single-species algal diets have been tested in an attempt to identify those diets that maximize the growth rate of abalone in culture. Day \& Fleming (1992) demonstrated that on some single-species algal diets $H$. rubra initially grew at a steady rate then failed to grow for the remainder of the trial, suggesting that nutrients were lacking in the diet. Stuart and Brown (1994) suggested that a variety of algae are better able to meet the preferences and nutritional requirements of cultured abalone over extended periods of time.

Kelp (E. maxima) is the most abundant algal species along the southwest coast of southern Africa, and is the most likely food source for abalone farms developing along this area of the coast (although in the northern west coast of South Africa and in Namibia it is largely replaced by Laminaria pallida (Grev. Ex J. Ag) (Stegenga et al., 1997). However, Stepto \& Cook (1993) found that E. maxima was the least preferred of three algae fed to $H$. midae. They suggested that this might be due to the high phenolic levels. Simpson \& Cook (1998) also stated that in a mixed diet it is likely that Ecklonia spp. would be avoided, which would negate the purpose of feeding Ecklonia spp. as part of a diet. Additionally, kelp is low in protein content (5 $\%)$ and high in water content (68-83 \%) (Hahn, 1989; Robertson-Anderson, 2004). All of this probably accounts for the relatively low growth obtained by the kelp only diet when compared against the other fresh seaweed combinations. In this study fresh kelp, however, is able to produce better growth than all dried feed including the formulated feed, Abfeed $囚$. This is in contrast to some studies (eg. Hahn, 1989; Britz, 1996b; Bautista-Teruel et al., 2003) who showed that growth rate of abalone fed formulated diets containing a combination of plant and animal protein sources (such 
as Abfeed $($ ) perform better than those fed diets with protein sources of plant origin only.

What then determines the feeding preference? Fleming (1995) suggested that preference for certain algae might be due to the presence of essential nutrients not available in other algae. A number of authors (Day \& Fleming, 1992; Fleming, 1995; Simpson \& Cook, 1998) showed that algae like Ulva and Gracilaria species constitute a poor diet when supplied singly, but they may be of great value when supplied as part of a mixed diet, thereby supplying essential nutrients to the diet. These studies however, referred to wild stocks and not protein-enriched Ulva and Gracilaria species as were used in this study. This probably accounts for the higher abalone growth on our mixed diet.

A number of previous studies have come to similar conclusions. Neori et al. (1998), for example, has shown that a number of Ulva spp. are able to remove up to $90 \%$ of dissolved nitrogen from aquaculture effluent. The culture of Ulva spp. in nutrient rich waters increases their protein content roughly 3 to 10 fold (Shpigel et al., 1999; Boarder \& Shpigel, 2001; Robertson-Andersson, 2004; Robertson-Andersson et al., 2005). This enriched Ulva has subsequently been shown to improve growth in, for example $H$. tuberculata (Neori et al., 1998; Shpigel et al. 1999), $H$. discus hannai (Shpigel et al., 1999), and H. roei (Boarder \& Shpigel, 2001).

The BW/SL ratio is an important determinant of the economic viability of different diets. The mixed diet has the greater ability to increase the ratio of body weight to shell length and our results have shown that although shell length growth rates of abalone fed on combination diets remained relatively constant over time, the body weight growth rates showed a significant increase over time. This is important for the commercial farmer, in that growth is dependent on the feed used for abalone aquaculture. The BW/SL ratio gives an indication of what feeds are more likely to produce better growth.

Natural diets of fresh seaweed, either as kelp alone or combinations of kelp and other seaweeds, produced the best growth in abalone, with the mixed diet performing best. Dried seaweed in any form produced the lowest growth. Although not as good as the fresh feeds, the formulated diet Abfeed $\AA$ as a single feed performs better than the dried seaweed feeds.

Acknowledgements

We would like to thank the Department of Biodiversity and Conservation Biology at the University of the Western Cape and the Jacobsbaai Sea Products farm for providing funding, research facilities and technical support. We also thank the South African National Research Foundation (NRF/Sweden collaboration), the Department of Environmental Affairs and Tourism, and the International Ocean Institute of Southern Africa for research funding. Deborah Robertson-Andersson provided valuable discussion. We thank Max Troell (University of Stockholm, Sweden) for the collaboration that has made this project a reality? 


\section{References}

Barkai, R. \& C.L. Griffiths, 1986. Diet of the South African abalone Haliotis midae. South African Journal of Marine Science 4: 37-44.

Barkai, R. \& C.L. Griffiths, 1987. Consumption, absorption efficiency, respiration and excretion in the South African abalone Haliotis midae. South African Journal of Marine Science 5: 523-529.

Bautista-Teruel, M.N., A.C. Fermin \& S.S. Koshio, 2003. Diet development and evaluation for juvenile abalone, Haliotis asinine and plant protein sources. Aquaculture 219: 645-653.

Boarder, S.J. \& M. Shpigel, 2001. Comparative growth performance of juvenile Haliotis roei fed on enriched Ulva rigida and various artificial diets. Journal of Shellfish Research 20: 653-657.

Britz, P.J., 1996a. Effects of dietary protein level on growth performance of South African abalone, Haliotis midae, fed on fishmeal based semi-purified diets. Aquaculture 140: 55-61.

Britz, P.J., 1996b. The suitability of selected protein sources for inclusion in formulated diets for the South African abalone Haliotis midae. Aquaculture 140: 6373 .

Britz, J.P., T. Hecht, J. Knauer \& M.G. Dixon, 1994. The development of an artificial feed for abalone farming. South African Journal of Science 90: 7-8.

Day, R.W. \& A.E. Fleming, 1992. The determinants and measurement of abalone growth. In Shepherd, S. A., M.J. Tegner \& S.A. Guzmán Del Próo (eds), Abalone of the World. Biology, Fisheries and Culture. Fishing News Books, Oxford: 141-168.

Duncan, A. \& R.Z. Klekowski, 1975. Parameters of an energy budget. In Grodzinski, W., R. Z. Klekowski, \& A. Ducan (eds), Methods for Ecological Bioenergetics. IBP Handbook. Blackwell Scientific Publications. Oxford: 97-148.

Fleming, A.E., 1995. Growth, intake, feed conversion efficiency and chemosensory preference of the Australian abalone, Haliotis rubra. Aquaculture 132: 297-31.

Fleming, A.E., R.J. van Barneveld \& P.W. Hone, 1996. The development of artificial diets for abalone: A review and future directions. Aquaculture 140: 5-53.

Genade, A.B., A.L. Hirst \& C.J Smit, 1988. Observations on the spawning, development and rearing of the South African abalone Haliotis midae Linn. South African Journal of Marine Science 6: 3-12.

Gerber, W.H. 2004. Enhancing the competitive advantage of the South African cultivated abalone industry. M.Sc. thesis, University of Stellenbosch, South Africa. Guzmán, J.M. \& M.T. Viana. 1998. Growth of abalone Haliotis fulgens fed diets with and without fish meal, compared to a commercial diet. Aquaculture 165: 321-33. 
Hahn, K.O., 1989. Nutrition and growth of abalone. In Hahn, K. O. (ed), Handbook of Culture of Abalone and Other Marine Gastropods. Florida: 135-156.

Leighton, D. L., 1974. The influence of temperature on larval and juvenile growth in three species of Southern California abalones. Fisheries Bulletin 72: 1137-1145.

Newman, G.G., 1968. Growth of the South African abalone Haliotis midae. Republic of South Africa Department of Industries, Division of Sea Fisheries, Investigational Report 67: 1-24.

Neori, A., N.L.C. Ragg \& M. Shpigel, 1998. The integrated culture of seaweed, abalone, fish and clams in modular intensive land-based systems: II. Performance and nitrogen partitioning within an abalone (Haliotis tuberculata) and macroalgae culture system. Aquacultural Engineering 17: 215-239.

Owen, B., L.H. Disaivo, E.E. Ebert \& E. Fonck, 1984. Culture of the California red abalone Haliotis rufescens Swanson (1822) in Chile. Veliger 27:101-105.

Robertson-Andersson, D. V., 2004. The cultivation of Ulva lactuca (Chlorophyta) in an intergrated aquaculture system, for the production of abalone feed and the bioremediation of aquaculture effluent. M.Sc. thesis, University of Cape Town, South Africa.

Robertson-Andersson, D. V., D. Leitao, J.J. Bolton, R.J. Anderson, A. Njobeni and K. Ruck, 2005. Can kelp extract (KELPAK®) be useful in seaweed mariculture? Hydrobiologia

Sales, J. \& P. J. Britz, 2001. Research on abalone (Haliotis midae L.) cultivation in South Africa. Aquaculture Research 32: 863-875.

Sales, J. \& G.P.J. Janssens, 2004. Use of feed ingredients in artificial diets for abalone: a brief update. Nutrition Abstracts and Reviews: Series B 74: 13N-21N.

Shepherd, S.A.\& P.D Steinberg, 1992. Food preference of three Australian abalone species with a review of the algal food of abalone. In Shepherd, S.A., M.J. Tegner \& Guzmán Del Próo (eds), Abalone of the World: Biology, Fisheries and Culture. Blackwell Scientific Publications, Oxford: 169-181.

Simpson, J.A. \& P.A.Cook, 1998. Rotation Diets: A method of improving growth of cultured abalone using natural algal diets. Journal of Shellfish Research 17: 635-640. Shpigel, M., N.L. Ragg, I. Lapatsch \& A. Neori. 1999. Protein content determines the nutritional value of the seaweed Ulva lactuca L. for the abalone Haliotis tuberculata L. and $H$. discus hannai Ino. Journal of Shellfish Research 18: 227-233.

Stegenga, H., J. J. Bolton \& R. J. Anderson, 1997. Seaweeds of the South African West Coast. Contributions from the Bolus Herbarium, University of Cape Town, 18: $655 \mathrm{pp}$.

Stepto, N.K. \& P.A. Cook, 1993. Feeding preferences of the juvenile South African abalone Haliotis midae (Linnaeus, 1758). Journal of Shellfish Research, 15: 653-657. 
Stuart, M.D. \& M.T. Brown, 1994. Growth and diet of cultivated black-footed abalone, Haliotis iris (Martyn). Aquaculture 127: 329-337.

Tutshulte, T.C., \& J.H. Connell, 1988. Feeding behaviour and algal food of three species of abalones (Haliotis) in southern California. Marine Ecology 49: 57-64.

Zar, J.H. 1984. Biostatistical Analysis. ${ }^{\text {nd }}$ ed. Prentice Hall, New Jersey: 718pp. 